\title{
Behavioral Comparisons of Ingestion and Excretion by Selected Species of Pentatomids: Evidence of Feeding on Different Food Sources Supports Pest Status
}

\author{
T LUCINI ${ }^{1}$, AR PANIZZI ${ }^{2}$ \\ ${ }^{1}$ Dept of Zoology, Federal Univ of Paraná, Curitiba, Brasil \\ ${ }^{2}$ Laboratory of Entomology, Embrapa Wheat, PO Box 3081, Passo Fundo, RS, Brasil
}

\section{Keywords}

Heteroptera, Electronic feeding monitoring, Feed frequency, Feeding time, Excretion

\section{Correspondence}

AR Panizzi, Laboratory of Entomology, Embrapa Wheat, PO Box 3081, Passo Fundo, 99001-970, RS, Brasil; antonio. panizzi@embrapa.br

Edited by Guilherme D Rossi - UNESP

Received 11 July 2016 and accepted 1 December 2016

Published online: 19 December 2016

(C) Sociedade Entomológica do Brasil 2016

\begin{abstract}
Laboratory studies were conducted on food ingestion and excretion by selected species of pentatomids on different food sources to support their pest status. We compared the frequency and time of feeding on vegetative (stem) and reproductive (seed) structures of soybean, Glycine $\max$ (L.) Merrill and of maize, Zea mays L. by Piezodorus guildinii (Westwood), Dichelops melacanthus (Dallas), and Edessa meditabunda (F.); in addition, the amount of excreta (feces) produced were compared for $D$. melacanthus feeding on seed of soybean and stem of maize seedling. The feeding behavior of $E$. meditabunda and $P$. guildinii on soybean, and of $D$. melacanthus on maize was recorded using the electropenetrography (EPG) technique. Excretion was estimated using water sensitive paper recording number and area of fecal drops. Results indicated that $E$. meditabunda on soybean stem repeated events of ingestion (both xylem and phloem sap) over four times per bug during the $8 \mathrm{~h}$ of recording for ca. 53 min per event. Dichelops melacanthus on maize seedling repeated each ingestion event over three times per bug for ca. 24 min per event. Piezodorus guildinii feeding on soybean stem repeated each ingestion 1.2 times per bug for ca. 40 min per event; on seed endosperm, it fed for a longer time, ca. 80 min per event, each event repeated only 0.5 times per bug. Number of excretory drops was higher ( 9.9 drops per bug) when D. melacanthus fed on maize seedling than on soybean seed (1.4 drops per bug). A larger amount of saliva/regurgitate liquid food was expelled when bugs fed on the former than on the later food.
\end{abstract}

\section{Introduction}

The majority of stink bugs (Heteroptera: Pentatomidae) feed on reproductive plant structures, fruits, and immature seeds (Schuh \& Slater 1995), because these are comprised of pockets of cells rich in essential nutrients (Slansky \& Panizzi 1987). However, some species prefer to feed on vegetative rather than reproductive structures. For example, the rice stink bug, Tibraca limbativentris Stål, prefers to feed on stems of rice (Rizzo 1976), and the brown-winged stink bug, Edessa meditabunda (F.), has preference for soybean stems rather than pods (Galileo \& Heinrichs 1979, Silva et al 2012).

In a different way, the small green stink bug, Piezodorus guildinii (Westwood), and the green-belly stink bug, Dichelops melacanthus (Dallas), are reported to prefer feeding on soybean pods (i.e., immature seeds). However, $D$. melacanthus, when faced with low availability of soybean pods, has been observed to feed on vegetative structures of gramineaceous plants, such as maize and wheat (Ávila \& Panizzi 1995, Chocorosqui \& Panizzi 2004, Manfredi-Coimbra et al 2005). 
It is hypothesized that stink bugs require more time and/ or greater repeat feeding events to obtain nutrients necessary for their development/reproduction on vegetative compared to reproductive structures, which have high water and low nutrient contents compared to seeds (Slansky \& Scriber 1985, Taiz \& Zeiger 2004).

A recent study using electropenetrographic (EPG) measurement of feeding by $E$. meditabunda on soybean stems showed that this species ingests from vascular tissues, primarily in xylem vessels, for a long duration, and repeatedly over time (Lucini \& Panizzi 2016). Thus, we suspect that stink bug feeding on vegetative structures (stems) excrete more and bigger fecal drops than insects feeding on reproductive structures (seeds). Therefore, in this study we (1) measured and compared the frequency (number of feeding events) and time (duration of feeding) of E. meditabunda on soybean stem, $P$. guildinii on soybean stem and on soybean seed, and D. melacanthus on maize stem and (2) investigated the number and size of excretion drops produced by D. melacanthus feeding on soybean seed and on maize stem.

\section{Material and Methods}

\section{Stink bug colonies}

Adults of $E$. meditabunda, $P$. guildinii, and $D$. melacanthus were collected in crop fields and taken to the entomology laboratory of the Embrapa Wheat Research Center located in Passo Fundo, RS, Brazil $\left(28^{\circ} 15^{\prime} \mathrm{S}, 52^{\circ} 24^{\prime} \mathrm{W}\right)$, where they were placed into plastic cages $(25 \times 20 \times 20 \mathrm{~cm})$ lined with filter paper. The cages were kept in a walk-in growth chamber at $25 \pm 1^{\circ} \mathrm{C}, 65 \pm 10 \%$ relative humidity, and L14:D10 photoperiod. For food, we provided a standard food source used to rear stink bugs in the laboratory, comprised of fresh green bean pods (Phaseolus vulgaris L.), mature soybean seeds (Glycine max (L.), raw shelled peanuts (Arachis hypogaea L.), and fruits (berries) of privet, Ligustrum lucidum Ait., which was replaced twice a week. To maintain the colony, eggs were collected from the rearing cages and placed inside small plastic boxes $(11 \times 11 \times 3.5 \mathrm{~cm})$ to raise young nymphs and obtain adults to be used in the tests.

\section{EPG recordings}

The feeding behavior of two soybean pests, $E$. meditabunda and $P$. guildinii, and one maize pest, $D$. melacanthus, was recorded using EPG. In this tool, the insects and plants are made part of a simple electrical circuit where current passes through the insect-plant interface; after the insect insert its stylets into plant tissue, the electrical circuit is closed, and the waveforms (representing feeding activities) are captured by the EPG monitor and recorded by a computer. Edessa meditabunda and $P$. guildinii were assessed on soybean stem (at V1 and V2 stages, respectively, of Fehr et al 1971), and in addition, the last species was assessed on soybean pods (seed endosperm-at pod-filling R5 stage of Fehr et al 1971); D. melacanthus was evaluated on stems of maize seedlings (at V2-V3 stage of Ritchie \& Hanway 1989).

All species assessed had their feeding behavior recorded continuously for $8 \mathrm{~h}$; the first species was recorded using a DC-monitor, Giga-8 model (EPG-Systems, Wageningen, the Netherlands) (Tjallingii 1988), using a fixed input impedance of $10^{9} \Omega$, and DC (direct current) applied signal. The other two species were recorded using the new AC-DC EPG monitor (Backus \& Bennett 2009; EPG Technologies, Inc., Gainesville, FL, USA), with an applied AC (alternating current) signal and various input impedance levels (from $10^{6}$ to $10^{13} \Omega$ ). That said, we used only data from recordings at input impedance of $10^{7} \Omega$ to calculate EPG variables. The complete methodology to record the feeding behavior of these species can be found in Lucini \& Panizzi (2016) and Lucini et al (2016).

\section{Number of fecal drops excreted by D. melacanthus}

Twenty plastic boxes-arenas $(11 \times 11 \times 3.5 \mathrm{~cm})$ were lined with water sensitive paper (Syngenta, Switzerland). We placed a single soybean imbibed for $24 \mathrm{~h}$ before use in each of ten arenas and a maize seedling (V2 stage) in each of the remaining ten arenas. A set of females of similar age (7-10 days old) were separated from the laboratory colony and placed in a rearing box without food (starvation time) for $15 \mathrm{~h}$ before being used in the experiment.

After the food deprivation period, a single female was selected and placed in each arena, and then all arenas were held under the same environmental conditions used for rearing the stink bugs. After $24 \mathrm{~h}$, the following variables were evaluated: mean number of fecal drops, area of each spot, number of drops $<1.5 \mathrm{~mm}$, and number of drops $>2.0 \mathrm{~mm}$. To determine the last three variables, each arena was photographed using a mobile phone, and then the photos were analyzed using the software ImageJ, v.1.47 (National Institutes of Health, MD, USA).

\section{EPG variables and statistical analysis}

The following EPG variables were calculated and determined for each feeding waveform from each stink bug species: NWEI (number of waveform events per insect), WDI (waveform duration per insect), and WDEI (waveform duration per event per insect) according to Backus et al (2007). The EPG variables were calculated based on the waveform libraries published for E. meditabunda (Lucini \& Panizzi 2016), for D. melacanthus (Lucini \& Panizzi 2017), and for P. guildinii (Lucini et al 2016). 
For the EPG variables [number of waveform events per insect (NWEI), waveform duration per insect (WDI), and waveform duration per event per insect (WDEI)], data were first subjected to the Bartlett test to check for homogeneity of variances. The $P$ values of NWEI, WDI, and WDEI were $2.2 \times 10^{-16}, 2.5 \times 10^{-7}$, and $4.1 \times 10^{-3}$, respectively, indicating that data did not fit the normal distribution. Therefore, we used the non-parametric Kruskal-Wallis test $(P<0.05)$ to compare the variables among stink bugs species. In order to separate the means of each stink bug species in each variable, the Duncan's multiple range test $(P<0.05)$ was applied.

The means of variables related to excretion of fecal drops (number of fecal drops, area of each spot, and groups of spot with different sizes) were separated through the Student's $t$ test $(P<0.05)$. All analyses were carried using R programming language, v.3.0.3 (R Development Core Team 2014).

\section{Results}

The Kruskal-Wallis non-parametric analysis indicated that differences for all EPG variables were highly significantly different for stink bugs species feeding on different food sources (NWEI $\chi^{2}=46.3, P<0.001$; WDI $\chi^{2}=38.6, P<0.001$; WDEI $\left.\chi^{2}=35.9, P<0.001\right)$. Electropenetrography of the feeding behavior of the stem feeder $E$. meditabunda on soybean plant demonstrated that each stink bug $(n=25)$ repeated ingestion events (xylem and phloem sap ingestion) over four times during the $8 \mathrm{~h}$ of recording (Fig 1), and the duration of ingestion time per insect was longer, ca. $210 \mathrm{~min}$ (Fig 2),

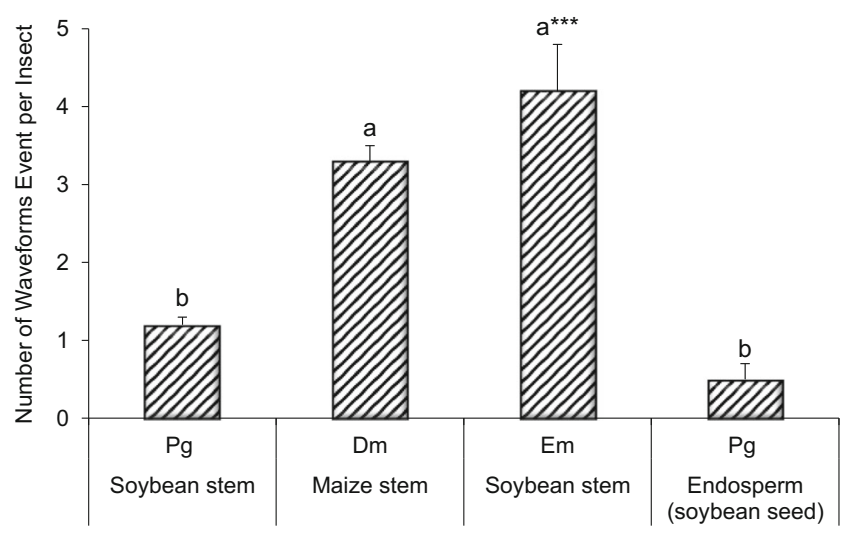

Fig 1 Mean $( \pm S E M)$ number of waveform events per insect (NWEI) for feeding recorded using EPG for three species of pentatomids ( $P g$ Piezodorus guildinii, Dm Dichelops melacanthus, and Em Edessa meditabunda), on vegetative (stem) and reproductive (seed) structures of different plants. Piezodorus guildinii feeding on soybean stem $(n=25)$ and on soybean pod (seed endosperm) $(n=17)$, Edessa meditabunda feeding on soybean stem $(n=25)$, and Dichelops melacanthus feeding on maize stem (seedling) $(n=21)$. Means followed by the same letters are not significantly different $(P<0.05$; Kruskal-Wallis and Duncan tests). ${ }^{* * *}$ Significant at $P<0.001$.

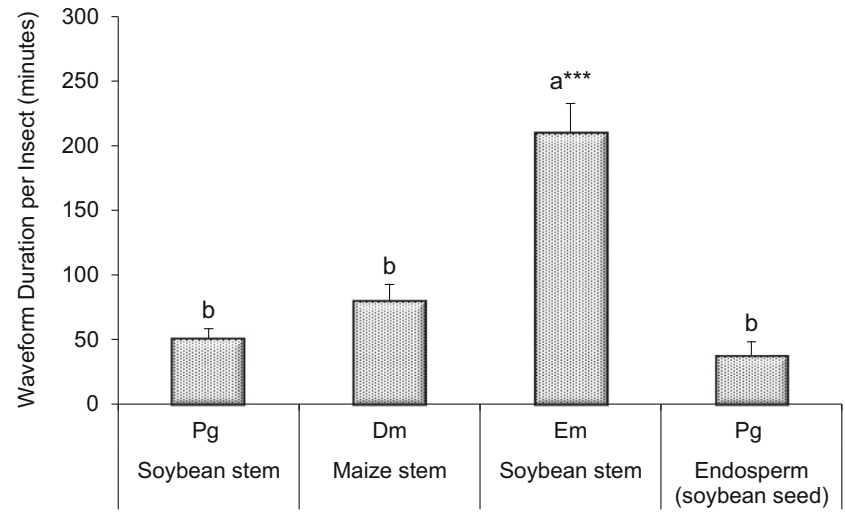

Fig 2 Mean $( \pm S E M)$ waveform duration per insect (WDI) (minutes) for feeding recorded using EPG for three species of pentatomids ( $P g$ Piezodorus guildinii, Dm Dichelops melacanthus, and Em Edessa meditabunda), on vegetative (stem) and reproductive (seed) structures of different plants. Piezodorus guildinii feeding on soybean stem $(n=25)$ and on soybean pod (seed endosperm) ( $n=17)$, Edessa meditabunda feeding on soybean stem $(n=25)$, and Dichelops melacanthus feeding on maize stem (seedling) $(n=21)$. Means followed by the same letters are not significantly different $(P<0.05$; Kruskal-Wallis and Duncan tests). ${ }^{* * *}$ Significant at $P<0.001$.

where each feeding event took a relatively long time, ca. 53 min (Fig 3).

For the EPG recordings ( $8 \mathrm{~h}$ ) of $D$. melacanthus on maize seedling, each individual bug spent ca. $80 \mathrm{~min}$ in overall feeding activities (WDI: Fig 2), and each feeding event had the shortest duration (ca. $24 \mathrm{~min}$ ) of all stink bugs evaluated on vegetative structures (Fig 3 ). However, similar to $E$. meditabunda, $D$. melacanthus repeated each feeding event several times, on average over three per bug $(n=21)$ (Fig 1). In contrast to the former two species, $P$. guildinii also

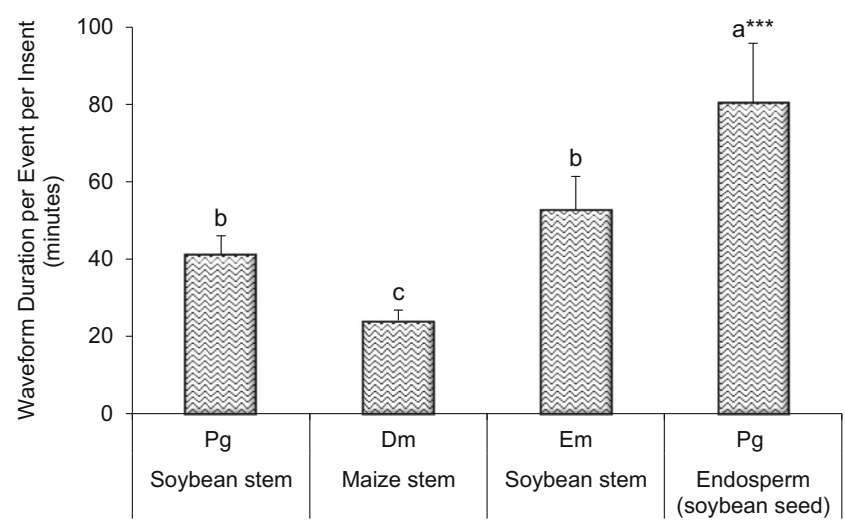

Fig 3 Mean ( \pm SEM) waveform duration per event per insect (WDEI) (minutes) for feeding recorded using EPG for three species of pentatomids ( $P g$ Piezodorus guildinii, Dm Dichelops melacanthus, and Em Edessa meditabunda), on vegetative (stem) and reproductive (seed) structures of different plants. Piezodorus guildinii feeding on soybean stem ( $n=25)$ and on soybean pod (seed endosperm) $(n=17)$, Edessa meditabunda feeding on soybean stem $(n=25)$, and Dichelops melacanthus feeding on maize stem (seedling) $(n=21)$. Means followed by the same letters are not significantly different $(P<0.05$; Kruskal-Wallis and Duncan tests). ${ }^{* * *}$ Significant at $P<0.001$. 
Fig 4 Mean ( \pm SEM) number of drops, number of drops $<1.5 \mathrm{~mm}$, number of drops $>2.0 \mathrm{~mm}$, and area of drops of liquid feces (all per insect) excreted by Dichelops melacanthus while feeding on water-turgid soybean seeds or maize seedling. Means within each variable with the same letter do not differ significantly by Student's $t$ test $(P<0.05, n=10)$. *Means on soybean seed were calculated considering the drops excreted by four insects; the remaining six did not excrete.
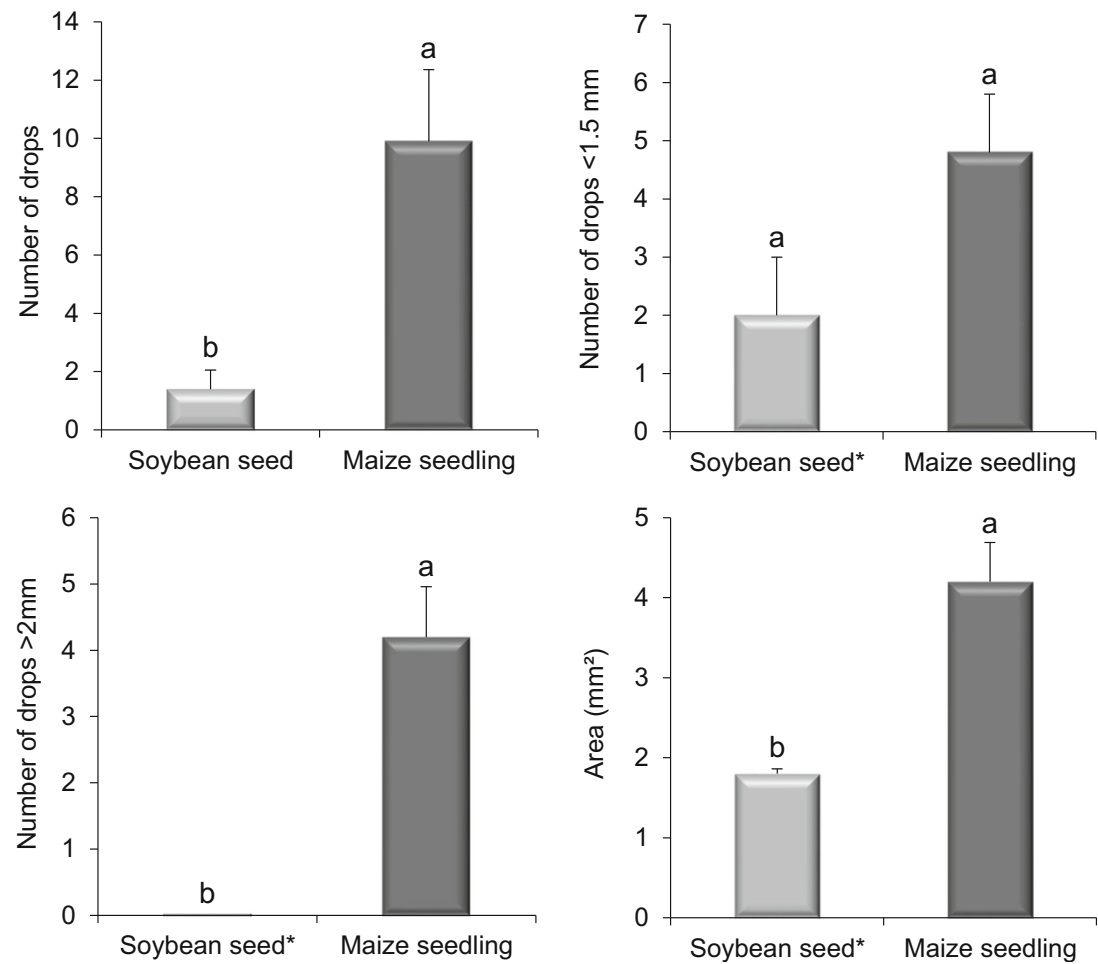

ingested liquid from xylem vessels during its feeding on soybean stem but it repeated each ingestion event no more than 1.2 times per bug ( $n=25$ ), and each bug spent ca. $51 \mathrm{~min}$ in feeding ingestion with a duration time of ca. 40 min per event on average (Figs 1, 2, and 3).

All stink bugs of these species evaluated on vegetative structure (stems of soybean or maize) fed at least one time each during the $8 \mathrm{~h}$ of recording. On soybean pods (seed endosperm), $P$. guildinii fed for a longer overall time, ca. 80 min per event; however, each event was repeated only 0.5 times per bug (Figs 1 and 3). Fifty percent of the bugs evaluated $(n=17)$ did not feed from endosperm during the $8 \mathrm{~h}$ of recording. Therefore, considering all stink bugs evaluated, each one spent less than 40 min feeding while on seed endosperm on average (Fig 2).

The comparison of fecal drops excreted by $D$. melacanthus feeding on two different substrates, water-turgid soybean seed and maize seedling, showed highly significant differences between substrates for most variables assessed. The mean number of drops excreted was higher when $D$. melacanthus fed on maize seedling (means of 9.9 drops per bug) than when fed on soybean seed (1.4 drops per bug) ( $t=3.34, P<0.01$ ) (Fig 4$)$. On this late food, only four bugs out of ten were observed to excrete drops, whereas on the maize seedling, all bugs did it.

For the number of drops $<1.5 \mathrm{~mm}$, there were no statistical differences ( $t=1.51, P=0.1619$ ) between treatments; however, there was a tendency for a higher number of drops on maize seedling, which showed 4.8 drops excreted per bug, than on soybean seed that showed 2.0 drops. The difference in number of drops $>\mathbf{2 . 0} \mathrm{mm}$ was highly significant ( $t=5.55, P<0.001$ ), with maize seedling showing the higher value with mean of 4.2 drops per bug, while on soybean seed, no drops $>2.0 \mathrm{~mm}$ were observed. There was also a statistical difference in the area of spots $(t=4.80, P<0.001)$, with larger spots on maize seedling $\left(4.2 \mathrm{~mm}^{2}\right)$ compared to soybean seed (1.8 $\mathrm{mm}^{2}$ ) (Fig 4).

It was interesting to observe that when $D$. melacanthus fed on maize seedling, a large amount of saliva/liquid food was expelled by all stink bugs tested (Fig $5 \mathrm{~A}$ ), whereas when they fed on soybean seed, the amount of expelled saliva/ liquid food was considerably lower (Fig 5B), and $80 \%$ of stink bugs expelled liquid.

\section{Discussion}

Stink bugs, in general, are polyphagous and exploit a large range of plants as food source. They prefer to feed on reproductive structures (fruits and seeds); however, sometimes these structures are not available in time and space, and they need to change their feeding behavior, i.e., changing from typical seed feeders to vegetative feeders-on leaves and stems, despite the latter sites being less preferred feeding sites by the majority of the species (Panizzi 2000, 2007; Panizzi \& Silva 2012). 


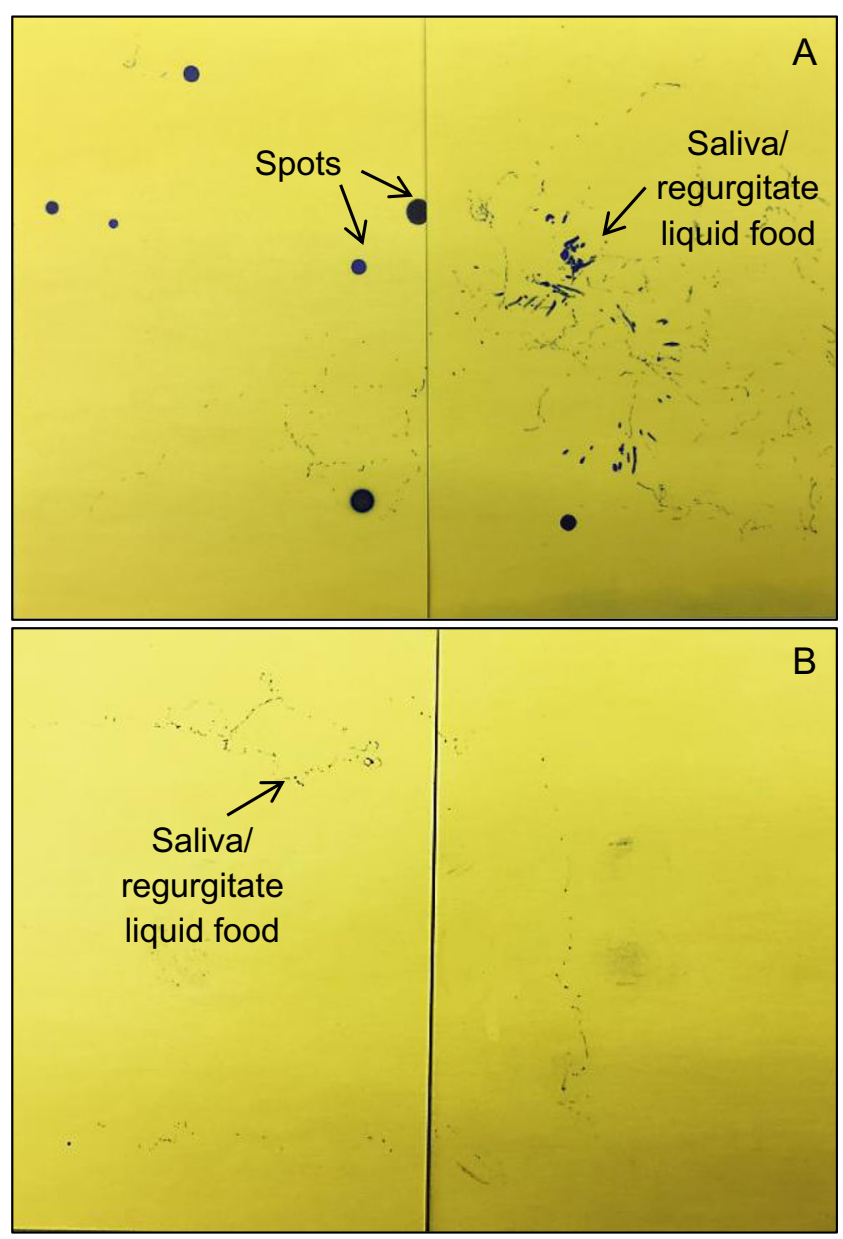

Fig 5 Excretory drops (round spots) and saliva/regurgitate liquid food (marks) out of the tip of the stylets on water sensitive paper produced by Dichelops melacanthus adults that fed on maize seedling $(\mathbf{A})$ and water-turgid soybean seed (B).

Piezodorus guildinii and D. melacanthus are reported to feed on soybean seed. The first species is considered a key pest on soybean fields in the Americas (Panizzi \& Slansky 1985), whereas $D$. melacanthus has been considered a secondary pest on this crop in the neotropics (Silva et al 2013). Nevertheless, D. melacanthus can feed on vegetative structures of gramineaceous plants such as wheat and maize. On these plants, the bugs are found feeding on seedlings, and this species has recently become an important pest on these crops (Chocorosqui \& Panizzi 2004, Manfredi-Coimbra et al 2005).

Seed suckers have a huge advantage compared with those species feeding on vegetative structures, because seeds are "packages" of balanced nutrients (Slansky \& Scriber 1985), stored in cells of the endosperm (reserve tissue of the seed). Seeds also possess low water content (ca. 5 to $15 \%$ of the mass). In contrast, in vegetative structures, cells have lower nutrient concentrations and high water content ( 80 to $95 \%$ ). Xylem cells transport water from roots to leaves (Taiz \& Zeiger 2004).
Species of stink bugs that prefer to feed on vegetative instead of reproductive structures, in general, require more frequent feeding periods (called events in EPG research) and/or perform longer feeding events, due to the nutritional composition and concentration of the food source. For instance, in our EPG study of E. meditabunda on soybean stem (preferred feeding site), each stink bug repeated the ingestion events (xylem and phloem sap ingestion) several times (mean of 4.2 times) during the recording period; in addition, each ingestion event lasted for almost $1 \mathrm{~h}$. Therefore, each stink bug spent, on average, ca. $45 \%$ of its recording time ingesting sap from xylem and phloem vessels.

During EPG recordings of $D$. melacanthus on stem of young maize plants, we observed that each feeding event lasted a much shorter period of time compared to feeding sessions of $E$. meditabunda on soybean stem. However, $D$. melacanthus showed a similar behavior, i.e., it ingested cell contents several times (mean of 3.3 times) during the recording period. Therefore, this relatively high feeding frequency is probably correlated with the high number and size of drops excreted by $D$. melacanthus observed while it fed on stem of maize seedlings.

Piezodorus guildinii also ingested liquids from xylem tissues for a long time (ca. 40 min each event) while feeding on soybean stem, but in contrast to $E$. meditabunda and $D$. melacanthus, it did not repeat each event several times, only 1.2 times per bug. According to Lucini et al (2016), P. guildinii probably ingests xylem sap mainly to avoid dehydration and to maintain water and nutrient balance, since it has preference to feed on soybean seed (endosperm), which has high nutrient concentration (Panizzi \& Slansky 1985). According to Saxena (1963), seed suckers feed mostly on dry seeds and require a large amount of water during its feeding activities, which is obtained by feeding on vegetative structures.

In summary, feeding of $E$. meditabunda on soybean stem showed the overall (i.e., WDI) highest feeding duration, by far, caused by a combination of large numbers (i.e., NWEI) of intermediate-duration (i.e., WDEI) feeding events. In contrast, feeding of $P$. guildinii on both soybean stems and seeds resulted in short overall durations, caused by a small number of intermediate-duration events. Dichelops melacanthus on maize stem also showed short overall duration of feeding; however, for this species, this result was caused by large numbers of very short-duration events. Thus, high frequency of events could cause either high or low overall feeding duration, depending upon per event durations.

Stink bugs feeding on seeds excreted fewer and smaller drops than bugs feeding on vegetative structures, probably because seeds have low water contents compared to vascular tissues (Taiz \& Zeiger 2004). Indeed, it was observed that $D$. melacanthus that were fed on water-turgid soybean seed excreted fewer and smaller fecal drops. In addition to low water contents of the seeds, the previous result is probably 
also related to the method used to obtain the nutrients from seeds, called lacerate/macerate tactic of cell rupture feeding strategy (Backus et al 2005). This strategy is used by $P$. guildinii to feed on soybean seed (Lucini et al 2016), and in the same way, $D$. melacanthus probably use this strategy on this food.

In this strategy, the stink bug needs to degrade the cells of reserve through mechanical (laceration) and chemical (maceration-enzymes) actions to later ingest the "slurry" of cell contents. Even though bugs fed for a long time on seeds, as observed with $P$. guildinii on seeds of soybean (ca. 80 min per event), this time does not represent only ingestion action, because most of the time is spent to prepare the tissue for ingestion (Lucini et al 2016), whereas in vascular tissues (xylem and phloem), the nutrients are promptly available to intake.

The fact that few (four out of ten) D. melacanthus kept in the arenas with water-turgid soybean seed produced fecal drops may indicate absence of feeding and/or short feeding events without excretion on this food source. Similarly, few $P$. guildinii (50\%) fed on soybean seed inside the pod during the recording period.

It is interesting to mention that the greater amount of liquid expelled by the bugs on vegetative tissues compared to when they fed on seeds might include (in addition to saliva) regurgitation or egestion of the excess of liquid taken during feeding. We noticed that the bugs often moved around dragging a droplet on the stylet tips-see print lines on water sensitive paper in Figs $5 \mathrm{~A}, \mathrm{~B}$. This also has been commonly observed for another species of pentatomid, Dichelops furcatus (F.) feeding on wheat leaves (Panizzi et al 2015).

In conclusion, our results demonstrate that stink bugs feeding on vegetative structures fed more often and excreted more fecal drops than those fed on seed endosperm and expelled more saliva/regurgitated liquid food. However, feeding events on seeds took longer probably to "prepare" this nutrient-concentrated-food for ingestion. These results support the minor pest status of E. meditabunda on soybean (i.e., despite feeding for longer time, the resulting damage on stems of the adult soybean plants is unnoticed). Results also support the major pest status of $P$. guildinii on soybean pods because feeding resulted in damaged seeds, and of $D$. melacanthus feeding on maize seedlings, because feeding resulted in severe injury and/or plant death.

Acknowledgments We thank Elaine A. Backus and an anonymous reviewer for critical reading of the manuscript and for improving its readability. We also thank Walter Boller for providing the water sensitive paper. This study was partially supported by the National Council of Research and Technology of Brazil (CNPq) grant 471517/2012-7 to A. R. $\mathrm{P}$. and by the scholarship from CAPES (Ministry of Education) of Brazil to T. L. in order to obtain the Doctor of Science (Entomology) degree at the Federal University of Paraná at Curitiba, Brazil. We also thank the Embrapa Unit at Passo Fundo, RS, for support. This study is approved by the Publication Committee of the Embrapa Wheat, Passo Fundo, RS, Brazil, under number 5383/2016.

\section{References}

Ávila CJ, Panizzi AR (1995) Occurrence and damage by Dichelops (Neodichelops) melacanthus (Dallas) (Heteroptera: Pentatomidae) on maize. An Soc Entomol Bras 24:193-194

Backus EA, Bennett WH (2009) The AC-DC correlation monitor: new EPG design with flexible input resistors to detect both $\mathrm{R}$ and emf components for any piercing-sucking hemipteran. J Insect Physiol 55:869884

Backus EA, Serrano MS, Ranger CM (2005) Mechanisms of hopperburn: an overview of insect taxonomy, behavior, and physiology. Annu Rev Entomol 50:125-151

Backus EA, Cline AR, Ellerseick MR, Serrano MS (2007) Lygus hesperus (Hemiptera: Miridae) feeding on cotton: new methods and parameters for analysis of nonsequential electrical penetration graph data. Ann Entomol Soc Am 100:296-310

Chocorosqui VR, Panizzi AR (2004) Impact of cultivation systems on Dichelops melacanthus (Dallas) (Heteroptera: Pentatomidae) populations and damage and its chemical control on wheat. Neotrop Entomol 33:487-492

Fehr WR, Caviness CE, Burmood DT, Pennington JS (1971) Stage of development descriptions for soybeans, Glycine max (L.) Merrill. Crop Sci 11:929-930

Galileo MHM, Heinrichs EA (1979) Danos causados à soja em diferentes níveis e épocas de infestação durante o crescimento. Pesq Agropec Brasil 14:279-272

Lucini T, Panizzi AR (2016) Waveform characterization of the soybean stem feeder Edessa meditabunda: overcoming the challenge of wiring pentatomids for EPG. Entomol Exp Appl 158:118-132

Lucini T, Panizzi AR (2017) Feeding behavior of the stink bug Dichelops melacanthus (Heteroptera: Pentatomidae) on maize seedlings: an EPG analysis of multiple input impedances and histology correlation. Ann Entomol Soc Am 110 (in press)

Lucini T, Panizzi AR, Backus EA (2016) Characterization of an EPG waveform library for redbanded stink bug, Piezodorus guildinii (Hemiptera: Pentatomidae), on soybean plants. Ann Entomol Soc Am 109:198-210

Manfredi-Coimbra S, Silva JJ, Chocorosqui VR, Panizzi AR (2005) Danos do percevejo barriga-verde Dichelops melacanthus (Dallas) (Heteroptera: Pentatomidae) em trigo. Cienc Rur 35:1243-1247

Panizzi AR (2000) Suboptimal nutrition and feeding behavior of hemipterans on less preferred plant food sources. An Soc Entomol Brasil 29: 1-12

Panizzi AR (2007) Nutritional ecology of plant feeding arthropods and IPM. In: Kogan M, Jepson P (eds) Perspectives in ecological theory and integrated pest management. Cambridge University Press, pp. 170222

Panizzi AR, Agostinetto A, Lucini T, Smaniotto LF, Pereira PRVS (2015) Manejo integrado dos percevejos barriga-verde, Dichelops spp. em trigo. Embrapa Trigo, Ser. Documentos 114, p 40

Panizzi AR, Silva FAC (2012) Insect bioecology and nutrition for integrated pest management (IPM). In: Panizzi AR, Parra JRP (eds) Insect bioecology and nutrition for integrated pest management. CRC Press, New York, pp. 687-704

Panizzi AR, Slansky F Jr (1985) Legume host impact on performance of adult Piezodorus guildinii (Westwood) (Hemiptera: Pentatomidae). Environ Entomol 14:237-242

R Development Core Team (2014) R: A language and environment for statistical computing. R foundation for statistical computing, Vienna, Austria. 
Ritchie S, Hanway JJ (1989) How a maize plant develops. lowa, lowa State University of Science and Technology, Cooperative Extension Service, Ames (Special Report n.48)

Rizzo HFE (1976) Hemípteros de interés agrícola. Hemisferio Sur, Buenos Aires

Saxena KN (1963) Mode of ingestion in a heteropterous insect Dysdercus koenigii (F.) (Pyrrhocoridae). J Insect Physiol 9:47-71

Schuh RT, Slater JA (1995) True bugs of the world (Hemiptera: Heteroptera). Classification and natural history. Cornelll University Press, Ithaca

Silva FAC, Silva JJ, Depieri RA, Panizzi AR (2012) Feeding activity, salivary amylase activity and superficial damage to soybean seed by adult Edessa meditabunda (F.) and Euschistus heros (F.) (Hemiptera: Pentatomidae). Neotrop Entomol 41:386-390
Silva JJ, Ventura MU, Silva FAC, Panizzi AR (2013) Population dynamics of Dichelops melacanthus (Dallas) (Heteroptera: Pentatomidae) on host plants. Neotrop Entomol 42:141-145

Slansky F Jr, Panizzi AR (1987) Nutritional ecology of seed-sucking insects. In: Slansky Jr F, Rodriguez JG (eds) Nutritional ecology of insects, mites, spiders, and related invertebrates. J. Wiley \& Sons, New York, pp. 283-320

Slansky F Jr, Scriber JM (1985) Food consumption and utilization. In: Kerkut GA, Gilbert LI (eds) Comprehensive insect physiology, biochemistry and pharmacology. Pergamon, Oxford, pp. 87-163

Taiz L, Zeiger E (2004) Plant physiology. Third Edition. Sinauer Associates Inc., Publishers, Sunderland MA.

Tjallingii WF (1988) Electrical recording of stylet penetration activities. In: Minks AK, Harrewjin P (eds) Aphids: their biology, natural enemies and control, vol 2B. Elsevier, Amsterdam, pp. 95-108 